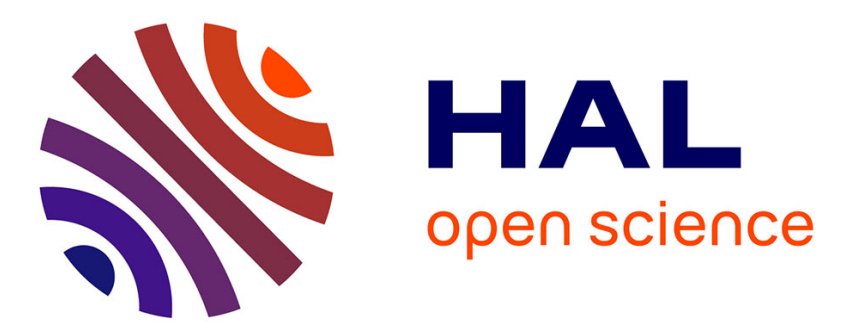

\title{
Chromatin Immunoprecipitation for Chromatin Interaction Analysis Using Paired-End-Tag (ChIA-PET) Sequencing in Tadpole Tissues
}

\author{
Nicolas Buisine, Xiaoan Ruan, Yijun Ruan, Laurent Sachs
}

\section{- To cite this version:}

Nicolas Buisine, Xiaoan Ruan, Yijun Ruan, Laurent Sachs. Chromatin Immunoprecipitation for Chromatin Interaction Analysis Using Paired-End-Tag (ChIA-PET) Sequencing in Tadpole Tissues. Cold Spring Harbor protocols, 2018, 13 (8), pdb.prot104620. 10.1101/pdb.prot097725 . hal-02864270

\author{
HAL Id: hal-02864270 \\ https://hal.science/hal-02864270
}

Submitted on 8 Jul 2020

HAL is a multi-disciplinary open access archive for the deposit and dissemination of scientific research documents, whether they are published or not. The documents may come from teaching and research institutions in France or abroad, or from public or private research centers.
L'archive ouverte pluridisciplinaire HAL, est destinée au dépôt et à la diffusion de documents scientifiques de niveau recherche, publiés ou non, émanant des établissements d'enseignement et de recherche français ou étrangers, des laboratoires publics ou privés. 
archives-ouvertes

\section{Chromatin Immunoprecipitation for Chromatin Interaction Analysis Using Paired-End-Tag (ChIA-PET) Sequencing in Tadpole Tissues}

Nicolas Buisine, Xiaoan Ruan, Yijun Ruan, Laurent Sachs

\section{To cite this version:}

Nicolas Buisine, Xiaoan Ruan, Yijun Ruan, Laurent Sachs. Chromatin Immunoprecipitation for Chromatin Interaction Analysis Using Paired-End-Tag (ChIA-PET) Sequencing in Tadpole Tissues. Cold Spring Harbor protocols, Cold Spring Harbor, NY: Cold Spring Harbor Laboratory Press, 2018, 13, 10.1101/pdb.prot097725 . hal-02864270

\section{HAL Id: hal-02864270 \\ https://hal.archives-ouvertes.fr/hal-02864270}

Submitted on 8 Jul 2020

HAL is a multi-disciplinary open access archive for the deposit and dissemination of scientific research documents, whether they are published or not. The documents may come from teaching and research institutions in France or abroad, or from public or private research centers.
L'archive ouverte pluridisciplinaire HAL, est destinée au dépôt et à la diffusion de documents scientifiques de niveau recherche, publiés ou non, émanant des établissements d'enseignement et de recherche français ou étrangers, des laboratoires publics ou privés. 


\title{
Chromatin Immunoprecipitation for Chromatin Interaction Analysis using Paired-End-Tag (ChIA-PET) Sequencing in Tadpole Tissues
}

\author{
Nicolas Buisine, ${ }^{1}$ Xiaoan Ruan, ${ }^{2}$ Yijun Ruan, ${ }^{2,3}$ and Laurent M. Sachs ${ }^{1,4}$ \\ ${ }^{1}$ Function and Mechanism of Action of Thyroid Hormone Receptor Group, UMR 7221 CNRS and Muséum \\ National d'Histoire Naturelle, Sorbonne Universités, Paris, France; ${ }^{2}$ The Jackson Laboratory of Genomic \\ Q1 Medicine, Farmington, Connecticut; ${ }^{3}$ The Department of Genetics and Developmental Biology, University of \\ Connecticut, Farmington, Connecticut
}

Proper gene expression involves communication between the regulatory elements and promoters of genes. Because regulatory elements can be located over a large range of genomic distances (from as close as a few hundred bp to as much as several $\mathrm{Mb}$ away), contact and communication between regulators and the core transcriptional machinery at promoters are mediated through DNA looping. Today, chromosome conformation capture (3C)-based methods efficiently probe chromosome folding in the nucleus and thus provide a molecular description of physical proximity between enhancer(s) and their target promoter(s). One such method, chromatin interaction analysis using pairedend-tag (ChIA-PET) sequencing, is a leading high-throughput method for detection of genome wide chromatin interactions. Briefly, the method involves cross-linkage of chromatin (-DNA) fibers in cells in situ, fragmentation of the fixed chromatin-DNA complexes by sonication, followed by enrichment of the chromatin complexes with a dedicated antibody through the process of immunoprecipitation (IP). Next, application of the ChIA-PET protocol followed by deep sequencing and mapping of reads to the reference genome reveals both binding sites and remote chromatin interactions mediated by the protein factors of interest. The method detailed here focuses on ChIP sample preparation and can be completed in $\sim 5 \mathrm{~d}$. The ChIA-PET method is detailed in an associated protocol. Because not all chromatin immunoprecipitation protocols are suitable for ChIA-PET, it is important to strictly follow this procedure before performing the ChIA-PET protocol.

It is essential that you consult the appropriate Material Safety Data Sheets and your institution's Environmental Health and Safety Office for proper handling of equipment and hazardous materials used in this protocol.

RECIPES: Please see the end of this protocol for recipes indicated by $<R>$. Additional recipes can be found online at http://cshprotocols.cshlp.org/site/recipes.

Reagents

Prepare all stock solutions in nuclease-free water unless noted.

Absolute ethanol (Carlo Erba 308609)

\footnotetext{
${ }^{4}$ Correspondence: sachs@mnhn.fr

From the Xenopus collection, edited by Hazel L. Sive.

Cite this protocol as Cold Spring Harb Protoc; doi:10.1101/pdb.prot097725
} 
Antibody to the protein of interest

AquaPhenol (water-saturated, $\mathrm{pH} 8$ for DNA extraction; MP Biomedicals 11AQUAPH01)

ChIP Assay Kit (Millipore 17-295)

Chromatin immunoprecipitation (ChIP) elution buffer $<\mathrm{R}>$

Chloroform (99+\% stabilized with amylenes; Sigma-Aldrich C2432)

Chromatin Immunoprecipitation Assay Kit (Millipore 17-295)

cOmplete, EDTA-free Proteinase Inhibitor Cocktail (Roche 11873580001)

DNA Ladder (100 bp; New England BioLabs N0467)

Formaldehyde (37\%; Fluka 93482)

Glycerol (Sigma-Aldrich G5516)

Glycine (1.25 M; Sigma-Aldrich G7126)

Glycogen from Mytilus edulis, Blue mussel (Sigma-Aldrich G1767)

Isopropyl alcohol (ACS for analysis; Carlo Erba 415154)

Nuclease-free water (Ambion AM9937)

Nuclei extraction buffer $<\mathrm{R}>$

Phenylmethylsulfonyl fluoride (PMSF; $0.1 \mathrm{M}$ in isopropanol; Fluka 93482)

Power SYBR Green PCR Master Mix (Applied Biosystems 4367659)

Proteinase K solution (2 g/L; Sigma-Aldrich P2308)

Quant-iT dsDNA HS Assay Kit (Invitrogen Q32851)

Real-time quantitative polymerase chain reaction reagents (described in Bilesimo et al. 2011)

Sodium acetate (3 M, pH 5.5; Ambion AM9740)

Sodium chloride (5 M; Sigma-Aldrich S3014)

SDS lysis buffer $<\mathrm{R}>$

This buffer is also found in the ChIP Assay Kit (Millipore 17-295).

SYBR Green (10,000×; Invitrogen S33102)

Tadpoles tissues, stage NF-54 (see Step 1)

Tris-acetate-EDTA (TAE) (10× buffer, pH 8.0; Invitrogen 15558-026)

UltraPure Agarose-1000 (Invitrogen 16550100)

Equipment

Aerosol pipette tips with high recovery, filter and wide orifice (VWR Europe 732-054 North America 46620-642)

Bioruptor sonicator (Diagenode) associated with a thermoregulator (NESLAB RTE7)

Q2

Cell strainer $(100 \mu \mathrm{m}$; BD 352360)

Centrifuge (benchtop; Sigma-Aldrich model 6K15 with rotor 11650 and swinging buckets 17677 for 50 - $\mathrm{mL}$ tubes or 17659 for $15-\mathrm{mL}$ tubes)

Centrifuge tubes (DNA LoBind, 1.5-mL, PCR clean; Eppendorf 0030 108.051)

Chemical hood

Dissecting microscope (Olympus, model SZ51)

Dounce homogenizer (Kontes Kimble, Wheaton)

Conical tubes (15 and $50 \mathrm{~mL}$; BD 352096 \& 352070)

Forceps (fine)

Freezer $\left(-80^{\circ} \mathrm{C}\right)$

Gel electrophoresis apparatus for $5 \times 5 \mathrm{~cm}$ gel

Gel imager (Bio-Rad Chemidoc Touch Imaging System)

Incubator for cross-linking (AquaLytic M83649)

MicroAmp Optical 96-Well Reaction Plate with Barcode (Applied Biosystems 4306737)

MicroAmp Optical Adhesive Film (Applied Biosystems 4311971)

Phase-lock gel light 1.5-mL tubes (5prime 2302800)

qPCR machine (Applied Biotechnology QStudio6 4485692) 
Qubit assay tubes (Invitrogen Q32856)

Qubit fluorometer (Invitrogen Q32857)

Refrigerated microcentrifuge (Eppendorf 5418R)

Rotary agitator (Stuart SB3, speed $13 \mathrm{rpm}$ )

Transfer pipettes with large opening (Dutscher Samco 043222S)

Transfer pipettes with small opening (Dutscher Samco 043233S)

Tube holder with metallic reflecting bar (Diagenode B01200013)

UV-visible spectrophotometer

Vortex mixer

Water bath

Reaching high immunoprecipitation enrichment is crucial for ChIA-PET and may require optimization. It is therefore essential to know a priori a least one DNA locus target that will serve as a gold standard for optimization. Additionally, efficiency of chromatin fragmentation and immunoprecipitation are strongly dependent on cell type and antibodies. Therefore, we strongly advise running a pilot experiment by subjecting a sample to the whole chromatin preparation and immunoprecipitation procedure, to set optimized parameters for antibody dilution, cross-linking-decross-linking duration time and temperature, and amount of tissue. Also, this pilot experiment will help estimate the number of parallel samples to process to reach sufficient chromatin quantities for ChIA-PET. Insufficient amounts of chromatin lead to a poor ChIA-PET library and dramatically increase the risk of failure. High amounts of material are required for each ChIA-PET sample. To illustrate, four chromatin samples produced from eight tail fin skins each (Steps 1 to 28), provide enough raw material for 20 chromatin immunoprecipitations (Step 29 to 46) which, once pooled, should reach the required amount ( $>50-100 \mathrm{ng}$ ) of precipitated material to proceed to Protocol: Chromatin Interaction Analysis Using Paired-End-Tag (ChIA-PET) Sequencing in Tadpole Tissues (Buisine et al. 2018). When comparing physiological states and/or treatments, one has to consider control and treated/stage specific samples as well as biological replicates. When no biological replicates are available, experimental validation with additional methods is strongly encouraged.

This protocol is a long and sensitive procedure. Particular attention should be given to quality controls at key steps to decide whether or not to proceed to the next step.

\section{Chromatin Isolation from Tissues}

1. Place tissues in an ice-cold microcentrifuge tube.

The following procedure is suited for eight tail fin skins, 12 hindlimb buds, eight livers, or eight brains of stage NF-54 tadpoles. To produce enough material for 20 chromatin immunoprecipitations, four chromatin samples should be prepared using, for example, 32 tail fin skins.

2. Add $1 \mathrm{~mL}$ of cold $\left(4^{\circ} \mathrm{C}\right)$ nuclei extraction buffer and transfer tissues and buffer to an ice-cold Dounce homogenizer on ice.

Nuclei Extraction Buffer without PMSF must be used within 5 h. Add PMSF in Nuclei Extraction Buffer just before use because the stability of PMSF is low.

3. Break the tissues by applying 10 strokes with the large clearance piston (type A) of the Dounce homogenizer.

This dissociates the tissues. The homogenizer should be kept on ice.

4. Transfer the homogenate to a microcentrifuge tube using a transfer pipette with a large opening.

5. Add $28 \mu \mathrm{L}$ of $37 \%$ formaldehyde.

The timing and concentration of formaldehyde treatment should be adapted to the cell samples and protein factors under investigation. Overfixed chromatin is difficult to manipulate and increases background signal, while too short of a treatment leads to a poor capture of chromatin interactions. To determine the best fixation parameters, we advise performing several pilot experiments (going through the whole procedure) with different fixation parameters. The parameters indicated here have been shown to work well with a variety of different tissues (skin, limb bud, liver, and brain) and may be a good starting point, but they are by no means universal. Other tissues may require additional optimization. This step is crucial and emphasis on establishing appropriate fixation parameters should not be underestimated. 
6. Incubate for $20 \mathrm{~min}$ on a rotary platform $(13 \mathrm{rpm})$ in an incubator set at $20^{\circ} \mathrm{C}$.

7. Add $114 \mu \mathrm{L}$ of $1.25 \mathrm{~m}$ glycine and incubate as in Step 6 for $5 \mathrm{~min}$.

8. Centrifuge at $2000 \mathrm{~g}$ for $2 \mathrm{~min}$ at $4^{\circ} \mathrm{C}$.

9. Discard the supernatant using a transfer pipette with narrow opening and place the tube on ice.

10. Resuspend the pellet in $1 \mathrm{~mL}$ of cold $\left(4^{\circ} \mathrm{C}\right)$ nuclei extraction buffer using a P1000 pipette.

11. Vortex the tube for $5 \mathrm{sec}$ and transfer the contents to a clean cold Dounce homogenizer using a transfer pipette with a large opening.

12. Break the cells by applying 10 strokes with the tight piston (type B) of the Dounce homogenizer. This leads to nucleus isolation. Keep the homogenizer on ice.

13. Transfer the homogenate with a narrow-opening transfer pipette to a $100 \mu \mathrm{m}$ cell strainer positioned on the top of a $50 \mathrm{~mL}$ conical tube.

14. Centrifuge at $2000 \mathrm{~g}$ for $2 \mathrm{~min}$ at $4^{\circ} \mathrm{C}$ in a centrifuge with swinging buckets.

15. Discard the supernatant using a P1000 pipette. Proceed immediately to Step 16.

\section{Chromatin Fragmentation}

16. Resuspend the nuclear pellet in $500 \mu \mathrm{L}$ of SDS lysis buffer using a P1000 pipette.

This step must be performed at room temperature to avoid SDS precipitation.

17. Transfer the suspension to a $15-\mathrm{mL}$ conical tube.

A hard plastic $15 \mathrm{~mL}$ tube (polystyrene or polyethylene-crystal clear tube) is preferred to increase sonication efficiency.

18. Close the tube with a cap attached to the metallic probe supplied by Diagenode.

Check that the probe does not contact the tube wall and is positioned at the center. The bar reflects the ultrasound and thus optimizes sonication efficiency (Diagenode-patented system).

19. Place the tube in the Bioruptor sonicator water bath. Shear the chromatin with the following power setting: high for $30 \mathrm{~min}$ total time (30 sec “on"/30 sec “off").

A refrigerated circulation bath set at $1^{\circ} \mathrm{C}$ is recommended to maintain constant temperature $\left(<10^{\circ} \mathrm{C}\right)$ and to avoid overheating that would reverse cross-linking and degrade chromatin. Note that sonication prevents SDS precipitation at this low temperature. Vigorous sonication is recommended because it has the advantage of "shaking off" nonspecific interactions compared to other modes of chromatin fragmentation. Sonication strength should be adapted to fit samples and proteins under investigation. We recommend following the guidelines provided by the sonicator manufacturer to find optimum sonication parameters. Be aware that sonication quality is assessed by two parameters: the size of the fragmented DNA (tested from Steps 22 to 28), and immunoprecipitation capacity.

20. Transfer the sonicated chromatin to a new microcentrifuge tube and centrifuge at $16,000 \mathrm{~g}$ for $10 \mathrm{~min}$ at $4^{\circ} \mathrm{C}$.

SDS precipitation has never been observed at this step.

21. Transfer the supernatant into a fresh microcentrifuge tube and place the tube on ice. Take $310 \mu \mathrm{L}$ aliquots, and store the rest of the sample at $-80^{\circ} \mathrm{C}$ until use (Step 29).

\section{Quality Control of Chromatin Fragmentation}

22. Measure the absorbance $\left(\mathrm{A}_{260}\right)$ of two $10 \mu \mathrm{L}$ aliquots from Step 21. Deduce the estimated DNA concentration from the average of the two measures.

Use SDS lysis buffer as a blank. A concentration between 100 and $300 \mathrm{ng} / \mu \mathrm{L}$ is expected. Supernatants (Step 21) with a lower concentration should be discarded because the material is too diluted and thus not suitable for immunoprecipitation. Supernatants (Step 21) with a higher concentration must be diluted because of the increased viscosity of the solution, which will affect DNA quantification. Adjust the concentration of each chromatin sample (supernatant) as necessary (see Step 29). 
23. Dilute a third $10 \mu \mathrm{L}$ aliquot of fragmented chromatin from Step 21 to a final DNA concentration between 100 and $300 \mathrm{ng} / \mu \mathrm{L}$. Take $10 \mu \mathrm{L}$ of the diluted sample, and add $0.8 \mu \mathrm{L}$ of $0.5 \mathrm{M} \mathrm{NaCl}$ and $2 \mu \mathrm{L}$ of $2 \mathrm{~g} / \mathrm{L}$ proteinase $\mathrm{K}$.

24. Incubate the sample from Step 23 overnight at $65^{\circ} \mathrm{C}$.

This procedure degrades proteins and reverses cross-link.

25. Take $5 \mu \mathrm{L}$ of the digested sheared chromatin from Step 24 and add $5 \mu \mathrm{L}$ of $50 \%$ glycerol solution.

Do not use loading buffer with dye because after agarose gel electrophoresis, bromophenol blue has an apparent migration similar to that of chromatin fragments and may prevent their visualization.

26. Load $10 \mu \mathrm{L}$ of the mix (digested sheared chromatin and glycerol from Step 25) and a DNA ladder on a $1 \times$ TAE, $1 \%$ agarose gel with SYBR Green.

27. Run the gel for $30 \mathrm{~min}$ at $50 \mathrm{~V}$ in $1 \times \mathrm{TAE}$ buffer.

Migration at low speed improves the resolution of DNA separation.

28. Visualize DNA with the gel imager.

Good quality DNA usually appears as a smear with fragment size ranging from 200 to $600 \mathrm{bp}$. Sometimes, migration can be affected by SDS precipitation. If this occurs, the remaining decross-linked DNA (Step 24) can be used to repeat the gel electrophoresis. If repeating the electrophoresis, first heat the tube at $37^{\circ} \mathrm{C}$ for a few seconds to completely dissolve the SDS.

See Troubleshooting.

\section{Chromatin Immunoprecipitation (ChIP)}

29. Thaw the sample(s) from Step 21. Adjust the concentration of the sonicated chromatin to $100 \mathrm{ng} / \mu \mathrm{L}$ with SDS lysis buffer in a $15-\mathrm{mL}$ conical tube. Mix, then aliquot the total amount of fragmented chromatin required for immunoprecipitation with the antibody of interest, for a negative control, and for evaluation of preimmunoprecipitation starting material to a new $15 \mathrm{~mL}$ conical tube (see below for details).

As a starting point, the amount of sheared chromatin to use for each precipitation is $10 \mu \mathrm{g}$. Given that the ChIA-PET protocol requires 50 to $100 \mathrm{ng}$ of purified immunoprecipitated DNA, it is necessary to adjust the number of samples to process accordingly (see note under the Method heading). We typically perform 20 immunoprecipitations. In addition, $30 \mu \mathrm{g}$ of sheared DNA are required to control the quality of the immunoprecipitation. This includes an aliquot of the precipitated material, a negative control (no-antibody immunoprecipitation or an immunoprecipitation with preimmune serum) and an input/starting material aliquot (10 $\mu \mathrm{g}$ for each). Overall, in our hands, the typical amount of starting chromatin should be around $240 \mu \mathrm{g}$. The sonicated chromatin should be kept at room temperature to avoid SDS precipitation. Use a $50 \mathrm{~mL}$ tube if the amount of chromatin required is higher than $120 \mu \mathrm{g}$.

30. Dilute the sonicated chromatin 10-fold with ChIP dilution buffer with protease inhibitors. Vortex to mix.

The ChIP Dilution Buffer is included in the ChIP Assay Kit from Millipore $(0.01 \%$ SDS, $1.1 \%$ Triton $X-100,1.2 \mathrm{~mm}$ EDTA, $16.7 \mathrm{~mm}$ Tris- $\mathrm{HCl}$ pH 8.1, $167 \mathrm{~mm} \mathrm{NaCl}$ ). One tablet of cOmplete, EDTA-free Proteinase Inhibitor Cocktail and $70 \mu \mathrm{L}$ of PMSF $(0.1 \mathrm{M})$ are added to every $7 \mathrm{~mL}$ of ChIP dilution buffer before use.

31. Add $80 \mu \mathrm{L}$ of Salmon Sperm DNA/Protein A agarose mix (from the ChIP Assay Kit) per $10 \mu \mathrm{g}$ of sonicated DNA. Incubate for $30 \mathrm{~min}$ at $4^{\circ} \mathrm{C}$ with agitation on a rotary platform.

This preclear step will reduce nonspecific background. Salmon Sperm DNA/Protein A agarose mix is included in the ChIP Assay Kit from Millipore (600 $\mu \mathrm{g}$ sonicated salmon sperm DNA, $1.5 \mathrm{mg}$ BSA, $4.5 \mathrm{mg}$ recombinant protein A), provided as a 50\% gel suspension in $10 \mathrm{~mm}$ Tris- $\mathrm{HCl} \mathrm{pH} 8,1 \mathrm{~mm}$ EDTA, $0.05 \%$ sodium azide, in a final volume of $3 \mathrm{~mL}$. Mix vigorously before use and pipette with large orifice pipette tips. Can be purchased independently (Millipore 16-157C). Appropriate protein A or G agarose should be used, according to the source of antibody.

32. Centrifuge at $2000 \mathrm{~g}$ for $3 \mathrm{~min}$ at $4^{\circ} \mathrm{C}$ in a centrifuge with swinging buckets and collect the supernatant in $1 \mathrm{~mL}$ fractions in 23 microcentrifuge tubes (20 for samples and three for no antibody controls). 
33. Add antibody at the desired final concentration to each $1 \mathrm{~mL}$ supernatant fraction, one of which will be used to estimate immunoprecipitation efficiency. Add preimmune serum (or no antibody) to one $1 \mathrm{~mL}$ supernatant fraction as a negative control. Reserve $100 \mu \mathrm{L}$ of the supernatant fraction $(\sim 10 \mu \mathrm{g})$ to estimate the input/starting material. Store this sample at $-20^{\circ} \mathrm{C}$ in a microcentrifuge tube.

The titer, batch, nature (mono/polyclonal) and source (mouse, sheep...) of antibodies strongly affect immunoprecipitation efficiency. This will have to be optimized in a pilot experiment.

34. Incubate tubes overnight at $4^{\circ} \mathrm{C}$ with rotation.

35. Add $60 \mu \mathrm{L}$ of Salmon Sperm DNA/Protein A agarose to each tube and incubate for $1 \mathrm{~h}$ at $4^{\circ} \mathrm{C}$ with rotation.

Use large orifice pipette tips.

36. Centrifuge tubes at $2000 \mathrm{~g}$ for $2 \mathrm{~min}$ at $4^{\circ} \mathrm{C}$ and discard the supernatants.

Carefully pipette the supernatant without disturbing the agarose pellet. The supernatant contains the unbound nonspecific sheared chromatin.

37. Wash the pellets with $1 \mathrm{~mL}$ of Low Salt Immune Complex Wash Buffer and incubate for $5 \mathrm{~min}$ at $4^{\circ} \mathrm{C}$ with rotation.

The Low Salt Immune Complex Wash Buffer is included in the ChIP Assay Kit from Millipore $(0.1 \%$ SDS, $1 \%$ Triton X-100, 2 mм EDTA, 20 mм Tris- $\mathrm{HCl}$ pH 8.1, $150 \mathrm{~mm} \mathrm{NaCl).}$

38. Centrifuge tubes at $2000 \mathrm{~g}$ for $2 \mathrm{~min}$ at $4^{\circ} \mathrm{C}$ and discard the supernatants. Carefully pipette the supernatant without disturbing the agarose pellet.

39. Wash the pellets with $1 \mathrm{~mL}$ of High Salt Immune Complex Wash Buffer and incubate for $5 \mathrm{~min}$ at $4^{\circ} \mathrm{C}$ with rotation.

The High Salt Immune Complex Wash Buffer is included in the ChIP Assay Kit from Millipore (0.1\% SDS, $1 \%$ Triton X-100, 2 mм EDTA, 20 mm Tris- $\mathrm{HCl}$ pH 8.1, $500 \mathrm{~mm} \mathrm{NaCl}$ ).

40. Centrifuge the tubes at $2000 \mathrm{~g}$ for $2 \mathrm{~min}$ at $4^{\circ} \mathrm{C}$ and discard the supernatants.

Carefully pipette the supernatant without disturbing the agarose pellet.

41. Wash the pellets with $1 \mathrm{~mL}$ of $\mathrm{LiCl}$ Immune Complex Wash Buffer and incubate for $5 \mathrm{~min}$ at $4^{\circ} \mathrm{C}$ with rotation.

The LiCl Immune Complex Wash Buffer is included in the ChIP Assay Kit from Millipore $(0.25 \mathrm{~m} \mathrm{LiCl,} \mathrm{1 \%}$ NP40, $1 \%$ deoxycholate, 1 mм EDTA, 10 mм Tris-HCl pH 8.1).

42. Centrifuge the tubes at $2000 \mathrm{~g}$ for $2 \mathrm{~min}$ at $4^{\circ} \mathrm{C}$ and discard the supernatant. Carefully pipette the supernatant without disturbing the agarose pellet.

43. Wash the pellets with $1 \mathrm{~mL}$ of TE Buffer and incubate for $5 \mathrm{~min}$ at $4^{\circ} \mathrm{C}$ with rotation. The TE Buffer is included in the ChIP Assay Kit from Millipore (1 mm EDTA, $10 \mathrm{~mm} \mathrm{Tris-HCl} \mathrm{pH} \mathrm{8).}$

44. Centrifuge the tubes at $2000 \mathrm{~g}$ for $2 \mathrm{~min}$ at $4^{\circ} \mathrm{C}$ and discard the supernatant.

Carefully pipette the supernatant without disturbing the agarose pellet.

45. Repeat Step 43.

46. Combine all the tubes where antibody has been added into a single $15 \mathrm{~mL}$ conical tube or in a single $50 \mathrm{~mL}$ conical tube if the number of tubes to pool is higher than 12 . Centrifuge at $2000 \mathrm{~g}$ for $2 \mathrm{~min}$ at $4^{\circ} \mathrm{C}$ and discard the supernatant. Add $60 \mu \mathrm{L}$ of TE for each pooled sample. Mix gently and take an aliquot for quality control $(120 \mu \mathrm{L})$. This amount $(120 \mu \mathrm{L})$ corresponds to the equivalent of one tube prepared at Step 33 and will be used to measure the quantity of ChIP-DNA fragments and the enrichment of the precipitation. Meanwhile, the remaining ChIP-DNA solution should be kept on ice before proceeding to the ChIA-PET protocol.

ChIP material is sensitive to protease and nuclease. Care should be taken to avoid contamination. ChIPDNA fragments can be stored at $4^{\circ} \mathrm{C}$ for up to 2 wk before ChIA-PET library construction. Avoid long term storage to limit elution of DNA fragments from the beads and chromatin degradation. 
47. Two tubes will be used to estimate immunoprecipitation efficiency: the $120 \mu \mathrm{L}$ aliquot from Step 46 , and the tube to which preimmune serum or no antibody was added at Step 33. Centrifuge these tubes at $2000 \mathrm{~g}$ for $2 \mathrm{~min}$ at $4^{\circ} \mathrm{C}$.

48. Discard the supernatants. Proceed to Step 49 to quantify immunoprecipitation efficiency. Carefully pipette the supernatant without disturbing the agarose pellet.

\section{Quantification of ChIP-DNA Fragments and Measure of the Fold Enrichment}

49. Add $100 \mu \mathrm{L}$ of ChIP elution buffer to the two tubes from Step 48 (ChIP with and without antibody).

50. Incubate $30 \mathrm{~min}$ with rotation at room temperature.

51. Thaw the input sample from Step 33 on ice.

52. To ChIP (with and without antibody) and input samples (Step 33), add $4 \mu \mathrm{L} 5 \mathrm{M} \mathrm{NaCl}, 2 \mu \mathrm{L}$ 0.5 м EDTA, $4 \mu \mathrm{L} 1 \mathrm{~m}$ Tris- $\mathrm{HCl}$ pH 6.1 and $2 \mu \mathrm{L} 2 \mathrm{~g} / \mathrm{L}$ Proteinase K. Mix vigorously. The $\mathrm{NaCl}, \mathrm{EDTA}$, and Tris-HCl solutions are included in the ChIP Assay Kit from Millipore.

53. Incubate overnight at $65^{\circ} \mathrm{C}$.

54. Centrifuge tubes briefly $(20 \mathrm{sec})$ at 13,000 $\mathrm{g}$ at room temperature to recover liquid from evaporation.

55. Add $300 \mu \mathrm{L}$ of nuclease-free $\mathrm{H}_{2} \mathrm{O}$ to each tube and centrifuge at $2000 \mathrm{~g}$ for $2 \mathrm{~min}$ at room temperature.

56. Centrifuge 3 Phase lock gel tubes at $13,000 \mathrm{~g}$ for $1 \mathrm{~min}$ at room temperature.

57. Transfer $400 \mu \mathrm{L}$ from each tube of the eluted chromatin from Step 55 into a Phase Lock Gel tube, avoiding pipetting agarose.

58. Add $200 \mu \mathrm{L}$ of chloroform and $200 \mu \mathrm{L}$ of phenol and mix gently by inversion of the tube to create an emulsion.

Do not vortex.

59. Centrifuge at $13,000 \mathrm{~g}$ for $5 \mathrm{~min}$ at room temperature.

60. Transfer the aqueous phase from each tube to a new microcentrifuge tube. The solid interface prevents pipetting the organic phase. Usually, around $440 \mu \mathrm{L}$ can be collected.

61. Add $44 \mu \mathrm{L}$ of $3 \mathrm{~m}$ sodium acetate $\mathrm{pH} 5.5,2 \mu \mathrm{L}$ of $20 \mathrm{mg} / \mathrm{mL}$ glycogen, and 1 volume of cold isopropyl alcohol (kept at $-20^{\circ} \mathrm{C}$ ). Vortex to mix.

62. Incubate at $-80^{\circ} \mathrm{C}$ for $15 \mathrm{~min}$. Check that the liquid is not frozen.

63. Centrifuge at $16,000 \mathrm{~g}$ for $30 \mathrm{~min}$ at $4^{\circ} \mathrm{C}$. Ensure the presence of a small white pellet, which can detach from the tube wall. Be careful not to disturb the pellet in Steps 64-67.

64. Discard the supernatant.

65. Wash pellet twice with $1 \mathrm{~mL}$ of ice-cold $70 \%$ ethanol (kept at $-20^{\circ} \mathrm{C}$ ).

66. Centrifuge at $16,000 \mathrm{~g}$ for $5 \mathrm{~min}$ at $4^{\circ} \mathrm{C}$ and remove supernatant after each wash.

67. Remove as much remaining ethanol as possible. To this end, centrifuge at 16,000g for $10 \mathrm{sec}$ at room temperature and remove the liquid with a pipette.

68. Air dry the pellet by leaving the tube open for no more than $5 \mathrm{~min}$ at room temperature. Do not over dry the pellet, which makes it more difficult to dissolve in $\mathrm{H}_{2} \mathrm{O}$.

69. Resuspend the pellet in $22 \mu \mathrm{L}$ of nuclease-free $\mathrm{H}_{2} \mathrm{O}$. Gently pipetting up and down can help. DNA can be stored at $-20^{\circ} \mathrm{C}$ until the next step. Avoid freeze-thaw cycles. 
70. Use two $2 \mu \mathrm{L}$ aliquots to measure DNA concentration using a Qubit fluorometer with the QuantiT dsDNA HS assay kit, as described by the manufacturer.

Use $200 \mu L$ Qubit assay tubes.

71. Measure precipitation enrichment by real time quantitative polymerase chain reaction as previously described (Bilesimo et al. 2011). We use Prism 7300 system software (Applied Biosystems) to analyze the results in auto determination of cycle time (ct) mode. Polymerase chain reaction (PCR) efficiency is calculated for each primer set from the slope of a standard curve (with $R^{2}>$ 0.99). The standard curve is a serial 10 -fold dilution of each input in the range of utilization for the ChIP assays. The first dilution corresponds to $10 \%$ of input, the second corresponds to $1 \%$ of input, and the last one corresponds to $0.1 \%$ and was chosen as a conservative base line of detection because the primer efficiency with dilutions under $0.05 \%$ of input decreased and the variability increased. The values for the input and experimental samples are calculated from the standard curve. Results are expressed as percent of input calculated as followed: $\%$ of input $=(\mathrm{AE})$ (Ct input $-\mathrm{Ct} \mathrm{ChIP}) \times \mathrm{Fd} \times 100 \%$, with $(\mathrm{AE})$ amplification efficiency of primer: 10-slope of standard curve (3.32), Ct input: mean of duplicates from dilution of input corresponding to 1\%, Ct ChIP: mean of duplicates from ChIP sample and Fd: compensatory factor to balance the difference in amounts of ChIP and input DNA taken for qPCR.

To measure the immunoprecipitation enrichment (ChIP signal normalized over input signal), compare the values between the samples with and without antibody (or preimmune serum), at a known DNA binding target of the protein of interest. In addition, values at a known DNA binding target should be highly contrasted compared to a negative control locus (no binding of the protein of interest). Primers must be well designed and tested.

See Troubleshooting.

72. Proceed to Protocol: Chromatin Interaction Analysis Using Paired-End-Tag (ChIA-PET) Sequencing in Tadpole Tissues (Buisine et al. 2018) only if a total of 50 to $100 \mathrm{ng}$ chromatin DNA is recovered. ChIA-PET also critically requires high immunoprecipitation enrichment. Successful experiments show an enrichment fold higher than 30 when comparing immunoprecipitation with and without antibody, and a binding contrast higher than 30-fold when comparing known binding locus versus no-binding locus (unpublished data). These threshold levels may be very specific to individual DNA-binding proteins.

Problem (Step 28): Incomplete fragmentation of chromatin by sonication and/or low amount of fragmented chromatin.

Solution: The expected size range of the fragmented chromatin DNA should be between 200 and $600 \mathrm{bp}$. In case of incomplete fragmentation (size range higher than $600 \mathrm{bp}$ ), avoid resonication and restart instead with a new batch of chromatin. The amount of sonicated material must be high enough for precipitation and library construction (see next problem).

Problem (Step 71): Low yield or low enrichment of chromatin immunoprecipitation products.

Solution: Yield of enriched chromatin-DNA on beads should be between 50 and $100 \mathrm{ng}$. Repeat immunoprecipitation and pool immunoprecipitation products until this yield is reached. Enrichment should be higher than 30-fold at a positive control DNA locus (a known DNA binding site for the protein of interest) after normalization using input DNA and negative control locus (at least 2000 bp away from the known binding site). If immunoprecipitation enrichment is too low, repeat immunoprecipitation with a new antibody (from a new batch or a new provider). Importantly, immunoprecipitation enrichment is batch dependent and should be evaluated for each antibody. 
In 2009, the Genome Institute of Singapore developed ChIA-PET to produce simultaneously, in a single experiment, a genome-wide binding profile, together with a map of the physical interactions between protein-bound DNA regions (Fullwood et al. 2009). The method was originally used for chromatin isolated from human cell lines (Fullwood et al. 2009; Handoko et al. 2011; Li et al. 2012; Zhang et al. 2013). In 2015, the method was used for the first time with chromatin isolated from Xenopus tropicalis tissues (Buisine et al. 2015). The objective was to better understand the molecular transcriptional mechanisms controlled by thyroid hormone and their receptors during metamorphosis. However, the ChIA-PET method is complex and thus requires high quality starting materials. Here, we describe a protocol for ChIP proven to provide appropriate products for ChIA-PET analysis. This protocol presents a powerful opportunity for Xenopus researchers to analyze gene regulation in the context of the 3D nucleus.

\section{RECIPES}

\section{Chromatin Immunoprecipitation (ChIP) Elution Buffer}

Freshly prepare a bicarbonate buffer by dissolving $84 \mathrm{mg}$ of $\mathrm{NaHCO}_{3}$ (Sigma-Aldrich S5761) in $9 \mathrm{~mL}$ of $\mathrm{H}_{2} \mathrm{O}$. Add $1 \mathrm{~mL}$ of 10\% SDS (Promega V6553).

Nuclei Extraction Buffer

\begin{tabular}{lrr} 
& $\begin{array}{c}\text { Amount to add } \\
\text { Reagent }\end{array}$ & $\begin{array}{r}\text { Final concentration } \\
(1 \times)\end{array}$ \\
\hline Triton X-100 (Sigma-Aldrich T8787) & $52.5 \mu \mathrm{L}$ & $0.5 \%$ \\
Tris-HCl (1 M, pH 7.5; ThermoFisher 15567-027) & $105 \mu \mathrm{L}$ & $10 \mathrm{~mm}$ \\
$\mathrm{CaCl}_{2}$ (1 M; Sigma-Aldrich C3306) & $31.5 \mu \mathrm{L}$ & $3 \mathrm{~mm}$ \\
Sucrose (Sigma-Aldrich S0369) & $882 \mathrm{mg}$ & $250 \mathrm{~mm}$ \\
DTT (0.1 M; Sigma-AldrichD9779) & $10.5 \mu \mathrm{L}$ & $0.1 \mathrm{~mm}$ \\
Complete Mini EDTA-free Proteinase Inhibitor & 1.5 tablets & $1 \times$ \\
$\quad$ Cocktail (Roche 11836170001) & & $1 \mathrm{~mm}$ \\
Phenylmethylsulfonyl fluoride (PMSF; 0.1 M in & $105 \mu \mathrm{L}$ &
\end{tabular}
isopropanol; Fluka 93482)

Store the buffer without protease inhibitors at $\mathrm{XX}^{\circ} \mathrm{C}$ for up to $\mathrm{XXXXXX}$. Add protease inhibitors (Complete Mini EDTA-free Proteinase Inhibitor Cocktail and PMSF) immediately before using the buffer.

SDS Lysis Buffer

\begin{tabular}{lrc} 
Reagent & $\begin{array}{r}\text { Amount to add } \\
\text { (for } 3.5 \mathrm{~mL})\end{array}$ & $\begin{array}{r}\text { Final concentration } \\
(1 \times)\end{array}$ \\
\hline SDS (10\%; Promega V6553) & $350 \mu \mathrm{L}$ & $1 \%$ \\
Tris-HCl (1 M, pH 8.1) & $70 \mu \mathrm{L}$ & $50 \mathrm{~mm}$ \\
EDTA (0.5 M, pH 8; Ambion AM9260G) & $175 \mu \mathrm{L}$ & $10 \mathrm{~mm}$ \\
Complete Mini EDTA-free Proteinase Inhibitor & 0.5 tablet & $1 \times$ \\
Cocktail (Roche 11836170001) & & $1 \mathrm{~mm}$ \\
Phenylmethylsulfonyl fluoride (PMSF; 0.1 M in & $35 \mu \mathrm{L}$ &
\end{tabular}
isopropanol; Fluka 93482)

Keep this buffer at room temperature to avoid SDS precipitation. Add protease inhibitors (Complete Mini EDTA-free Proteinase Inhibitor Cocktail and PMSF) immediately before using the buffer. 


\section{REFERENCES}

Bilesimo P, Jolivet P, Alfama G, Le Mevel S, Havis E, Demeneix BA, Sachs LM. 2011. Specific histone lysine 4 methylation patterns define TRbinding capacity and differentiate direct $\mathrm{T}_{3}$ responses. Mol Endoc 25: 225-237.

Buisine N, Ruan X, Bilesimo P, Grimaldi A, Alfama G, Ariyaratne P, Mulawadi F, Chen J, Sung WK, Liu ET, et al. 2015. Xenopus tropicalis genome re-scaffolding and re-annotation reach the resolution for in vivo ChIAPET analysis. PLoS One 10: e0137526.

Buisine N, Ruan X, Ruan Y, Sachs LM. 2018. Chromatin interaction analysis using paired-end-tag (ChIA-PET) sequencing in tadpole tissues. Cold Spring Harb Protoc doi: 10.1101/pdb.prot 104620.

Fullwood MJ, Liu MH, Pan YF, Liu J, Xu H, Mohamed YB, Orlov YL, Velkov S, Ho A, Mei PH, et al. 2009. An oestrogen-receptor-alpha-bound human chromatin interactome. Nature 462: 58-64.
Handoko L, Xu H, Li G, Ngan CY, Chew E, Schnapp M, Lee CW, Ye C, Ping JL, Mulawadi F, et al. 2011. CTCF-mediated functional chromatin interactome in pluripotent cells. Nat Genet 43: 630-638.

Li G, Ruan X, Auerbach RK, Sandhu KS, Zheng M, Wang P, Poh HM, Goh Y, Lim J, Zhang J, et al. 2012. Extensive promoter-centered chromatin interactions provide a topological basis for transcription regulation. Cell 148: 84-98.

Zhang Y, Wong CH, Birnbaum RY, Li G, Favaro R, Ngan CY, Lim J, Tai E, Poh HM, Wong E, et al. 2013. Chromatin connectivity maps reveal dynamic promoter-enhancer long-range associations. Nature 504: 306-310. 


\section{Prot097725}

\section{Queries}

Q1 Please provide postal codes for affiliations.

Q2 Please check units (" $\mu \mathrm{m}$ ") used to describe cell strainer. (You originally wrote " $\mu \mathrm{M}$ ".)

Q3 For each of your recipes, please indicate storage conditions (temp and how long it will last, if known). If the solution must be prepared in advance, please indicate that instead. 